\title{
Transaction Costs and Institutions' Efficiency: A Critical Approach
}

\author{
By COSMin Marinescu
}

\begin{abstract}
Institutions cannot "work" by themselves, that is, without necessary efforts for enforcing, preserving, and improving them. For many economists, these efforts represent the costs of the economic system at work. Nowadays in institutional economics, the costs of running the economic system are generally called "transaction costs." This article will offer a critical approach on the significance of transaction costs. This study highlights the necessity of subordinating the efficiency criterion to the ethics criterion, not only in the human action area, but mostly in institutions, as rules of the game in the society.
\end{abstract}

\section{Institutions, Human Action, and Transaction Costs}

Institutional economics founds itself on recognizing the fact that human action and its results must be fundamentally analyzed in connection with the economic, social, and political rules that govern human action in the society. ${ }^{1}$ Thus, the economic approach on institutions is focused on identifying the optimal institutional arrangement, given the obvious possibilities of the normative analysis of alternative institutional arrangements (see Eggertsson 1990; Pejovich 1995). Nowadays, economists consider that economic performance depends strongly on the societal institutional framework.

In the institutional approach of Douglass North, the theory of institutions "is constructed from a theory of human behavior com-

Cosmin Marinescu is an Associate Professor at the Economics Department, the Academy of Economic Studies, Bucharest. He has published in the fields of institutional economics and Austrian economics. Recently, within the Centre for Economics and Liberty (ECOL; www.ecol.ro), he coordinated the volume Market Economy. Institutional Foundations of Prosperity, about free market institutions and building the market economy in post-communist Romania. E-mail: marinescu@gmail.com

This article is supported by the Sectorial Operational Programme Human Resources Development (SOP HRD), financed from the European Social Fund and by the Romanian government under the contract number SOP HRD/89/1.5/S/62988.

American Journal of Economics and Sociology, Vol. 71, No. 2 (April, 2012).

(C) 2012 American Journal of Economics and Sociology, Inc. 
bined with a theory of the costs of transacting" (North 1990:27). By combining these theories, one can understand why institutions exist and what role they play in the functioning of the society. North also mentions that if you add the theory of production, one can analyze the institutions' implication on the economic performance.

It is obvious that the immutable role of the social institutions is to reduce and limit the uncertainty of human cooperation, to give a steady structure for everyday life. With no intention to underestimate the role of social institutions in the reduction of uncertainty, this paper will emphasize the irrelevance of the transaction costs criteria, as objective sources of valuation of the institutions' efficiency. Contrary to North and other mainstream institutionalists, when the human action theory is combined with the transaction costs theory, the result can be exactly the misappropriation of the fundamental criteria according to which we have to judge the institutions and institutional change. In fact, a real human action theory is one that necessarily includes the (transactional) essence of the human interaction costs. In order to lay the scientific foundations of an economic theory of the institutions and, at the same time, to find out the role of the institutions upon prosperity, a real human action theory does not need to be combined with a hypothetical transaction costs theory. This paper will also emphasize the implications of the institutions' utilitarian approach in the economic science and public debates on politics.

One may ask whether there had ever been any other two words in the economic literature that generate as much friction as "transaction costs?"2 The economics of transaction costs began with "The Nature of Firm," the famous article of Ronald Coase from 1937. ${ }^{3}$ The Swedish Bank Prize in Economics laureate, Ronald Coase explains the existence of the firm and the integration of the activities from this kind of organizational structure using the transaction cost concept- "the cost of using the price mechanism" in the original terminology of (Coase 1937: 390). But, as Oliver Williamson shows (Williamson and Winter 1991: 8), "one could say that Coase's approach on the transaction costs did not face time as well as the theory [of firm], on the whole." In "The Nature of the Firm," Coase neither defined the empiric character of transaction costs, nor explained how these could be recognized. Despite all contradictions regarding the transaction costs, today this 
theory represents the cornerstone of efficiency analyses on comparative institutional arrangements. ${ }^{4}$ These analyses are focused on the role transaction costs play in determining the distribution of property rights; broadly defined as all laws, rules, social customs, and organizations that generate incentives for human action.

The economic theory reveals the universal fact that any human action entails a cost, as human action means choice, and therefore sacrifices and foregone opportunities. Accordingly, doing a transaction has a cost; conceptually, the transaction cost phenomenon becomes easily accepted (see Williamson 1979: 234). The major difficulty is in the operationalization of these costs. Consequently, it can be said that transaction costs represent more a way of giving arguments than an efficiency indicator of empiric nature. The confusion derives from the fact that transaction costs are considered as an indicator used in order to appreciate the superiority of institutions and institutional arrangements. For example, according to Douglass North, the costly character of information represents the key to transaction costs:

The costliness of information is the key to the costs of transacting, which consist of the costs of measuring the valuable attributes of what is being exchanged and the costs of protecting rights and policing and enforcing agreements. These measurement and enforcement costs are the sources of social, political, and economic institutions. (North 1990: 27)

On the whole, within the transaction costs category, economists include information costs, negotiating costs, the costs of writing contracts, the costs of protecting property rights, and the costs of enforcing rules and agreements from different contractual arrangements. The problem of "measuring valuable attributes of what is changing" reveals the objectivist perspective on which North (1990: 27) built his theory. However, the subjectivist paradigm, which the entire modern theory of value is built on, excludes any possibility of objective valuation (external) for the costs involved by human action as a choosing process.

The real foundations of economic science are built on the opportunity cost theory. This does not prescribe a specific type of cost, but an economic way of thinking through which individuals' behavior in society is explained. In fact, the central argument comes from the very simple idea that the cost phenomenon derives naturally from human 
action, which means choice and exchange. Therefore, the cost's significance is the foregone satisfaction: the value of the best sacrificed opportunity (as economics textbooks show).

Economic science also teaches us that valuations determining human choices are, necessarily, ex-ante and subjective economic categories. These valuations represent the importance, utility, or value that the individual gives to the goods and events taken into consideration. Today, despite many inconsistencies in mainstream or neoclassical economics, the theory of subjective value is the cornerstone of economic science, as demonstrated for more than a century by the economists of the Austrian School. ${ }^{5}$ For example, in one of the most quoted papers dedicated to the cost economic theory, the Swedish Bank Prize in Economics laureate James Buchanan emphasizes, too, that all costs that influence our decisions are always subjectivist valuations reported to potential opportunities. ${ }^{6}$ The source of these conclusions is derived from the economic way of thinking of the Austrians Ludwig von Mises and Friedrich von Hayek, whose influence on the research of the London School of Economics was significant. ${ }^{7}$

Cost (including transactions costs) analysis has to start with emphasizing the distinction between the measurable objective cost (the accountancy cost) and the cost as a subjective essential element for the choice process (the economic cost). Within the neoclassical theory, the cost has a material dimension, without being presented through the distinction ex ante-ex post. The formal theory of human action is based on the recognition of the fact that the cost phenomenon, which is impossible to be separated from the choice process, has a subjective nature regarding value and utility, as Menger (1871) demonstrated a long time ago. This perspective reveals inseparable difficulties as to when to make transaction costs operational or when to appreciate their influences. Murray Rothbard pointed out the real nature of cost when he wrote:

But if costs, like utilities, are subjective, nonadditive, and noncomparable, then of course any concept of social costs, including transaction costs, becomes meaningless. And third, even within each individual, costs are not objective or observable by any external observer. For an individual's cost is subjective and ephemeral; it appears only ex-ante, at the moment before the individual makes a decision. The cost of any individual's choice is his 
subjective estimate of the value ranking of the highest value foregone from making his choice. (Rothbard 1997: 269)

Despite these arguments against the possibility of making transaction costs operational, almost all approaches on New Institutional Economics use transaction costs as a criterion for the efficiency of institutions. For example, inefficiency is explained by high transaction costs, assimilated to a presumed failure for the parts of an exchange when trying to obtain information over the exchange terms. The secret of obtaining efficiency could be the decrease in transaction costsRonald Coase's famous idea:

The argument has proceeded up to this point on the assumption ... that there were no costs involved in carrying out market transactions. This is, of course, a very unrealistic assumption. In order to carry out a market transaction, it is necessary to discover who it is that one wishes to deal with, to inform people that one wishes to deal and on what terms, to conduct negotiations leading up to a bargain, to draw up the contract, to undertake the inspection needed to make sure that the terms of the contract are being observed, and so on. These operations are often extremely costly, sufficiently costly at any rate to prevent many transactions that would be carried out in a world in which the pricing system worked without cost. (Coase 1990: 114)

The conclusion could be that if potential exchange parts can be better informed or more able to communicate with each other, then it would not be unconsumed exchanges and losses in regards to the property rights value. This perspective, however, involves difficulties that are impossible to overcome. For the external observer, the existence of unconsumed exchanges does not necessarily reveal a lack of information and communication or institutional inefficiency. The real problem consists in the difficulty to reveal the existence of transaction costs and also the impossibility to measure these costs. ${ }^{8}$ On the other hand, the implications of the entrepreneurship in institutional change processes must be taken into consideration. Let us presume that an actual institutional arrangement does not reveal, through market process, the "relevant knowledge" from the Hayek (1945) approach. So, initial institutional arrangements are appreciated to be "inefficient." Under the given circumstances, the entrepreneurial process will generate institutional change over the buman action, but not the buman designed model. 
Let us consider the following example à la James Buchanan (1985): there are two villages, Cosmin and Marinescu, which do not communicate with each other. In the first village two pheasants are exchanged for a beaver. In the other village, two beavers are exchanged for a pheasant. In conditions of isolation, allocation results can be considered efficient because there is a free market within every village. Although, the condition that the market specific to each village is isolated, obtaining maximum earnings, equivalent to the two markets' integration, is not allowed. So, the entrepreneurship activity (the speculative one) will try to collect the advantages of this inefficient arrangement, which will, sooner or later, generate the exchange between the two villages.

Trying to anticipate price discrepancies for the same product, as in the previous example, indicates the existence of profit opportunities (incorporated in the price structure). These opportunities will enhance entrepreneurship, which will adjust the inefficiency of isolation. Profit opportunities stimulate entrepreneurship, which can, thus, improve the efficiency of the allocation process. As a consequence, the institutional constraints and incentives will be restructured by free market and competition forces. These factors improve the communication and informational environment.

On the free market, entrepreneurship is not just the result of the existing institutions, but it itself creates new institutional incentives and constraints, and unblocks organizational inertia.? Therefore, entrepreneurship can be considered the fundamental source of institutional change, not just its catalyst, as it appears in North's approach. ${ }^{10}$ As Israel Kirzner (1963:304) argues, on the free market, profit opportunities sustain competition; "if the greatest entrepreneurship talent is insufficient for removing all 'misallocations', even giving the profit reason, then the rest of 'misallocations' are simply undetectable." 11

According to the above mentioned example, I consider it is exaggerated and unfair in the meantime to suggest that the initial institutional arrangement (isolation of the two villages markets) prevents efficient allocation because of the transaction costs barrier. Free exchange means including entrepreneurship efforts to obtain all possible exchange earnings, which means recognizing the existence of 
informational and communication constraints' permanent restructuring. If present constraints are artificially imposed, by means of politics or administrative rules, the entrepreneurship that may generate the exchange barriers' optimal restructuring cannot be stimulated or can even be stopped. Given these artificial constraints conditions, which do not allow volunteer agreement on the property rights involved, the allocation frame can be labeled as inefficient, as Buchanan shows (1985: 98).

So, a positive transaction costs world is one in which transaction cost—despite a neutral approach of Barzel (1997: 12)—are rather imposed by state institutional constraints. But, even in these conditions, entrepreneurship becomes the mark of economic (dis)equilibrium.

\section{Market Transaction Costs vs. State Imposed Transaction Costs}

For my approach towards institutional economics, I think it is vital to make a terminological and factual distinction between market transaction costs - the existence of which in the human action area is natural and inevitable-and the state imposed transaction costswhich are an external source to the economic order of the market, as a result of the constraint of any state institutional arrangement. According to this point of view, imposed transaction costs would be the totality of costs and efforts made by the entrepreneurs and the market participants in general, in order to be in accordance with the formal institutional framework that the ruling political system enforces in society.

In North's approach towards institutions and economic performance, the significance of transaction costs comes as a continuation of a simple idea, gradually promoted as a scientific postulate: economic performance depends on low transaction costs. Such a theorem, apparently self-sufficient, still raises the issue of its own empirical consistency. If, by "low transaction costs" we understand the owners' total freedom to orientate the resources towards the most valuable uses, according to their subjective evaluations, then the postulate can absolutely proclaim its consistency according to the degree of economic freedom. 
I think that the dissociation of the market transaction costs from the state imposed transaction costs is the only way that, from a methodological and conceptual point of view, allows for an evaluation of the transaction costs in relation to the economic development and institutional change.

Market transaction costs are the defining phenomenon of any market relation, like all exchanges, any transaction requires information sharing, resources, and sacrificed time. The exchange cannot take place unless one assumes resource consumption, identifies and evaluates the prospective participants in the transaction and their offers, negotiates the terms and the exchanges, draws up the contracts, monitors the fulfilment of contractual obligations, as well as penalizes the commercial partners in case they do not respect the contractual terms. Given the free market, only the free will at work-based on the logical strictness of the cost-benefit type economic calculus-will establish what transaction costs are beneficial to the individuals' actions. In this case, transaction costs cannot be regarded any more as obstacles, but as vital ingredients in the success of human action in general, and in economic area in particular.

Imposed transaction costs are the corollary of the existence and functioning of the external institutional arrangement, that is, of the entire rules, regulations, and norms that define the state system. More exactly, here, we talk about the many constraints and costs that the national state imposes on most of the social life domains; from the costs to comply with the existing legislation in the fields of property, fiscal, labor market and labor contracts, finance and banking, monetary, etc. ${ }^{12}$ Only this category of transaction costs can be empirically modeled in the equation of economic development, and only the imposed transaction costs can be the focus of institutional reform strategies that would take into consideration the reform of the present administrative institutions, so that the burden of their operation on the economy might be as reduced as much as possible.

Therefore, a reduced level of the imposed transaction costs is the feature of an institutional arrangement in the neighborhood of the free market system. Similarly, a high level of the imposed transaction costs is the indicator of an interventionist institutional arrangement, where the state puts many consistent institutional constraints in the way of 
the economic activity. From this we deduce that a business environment characterized by a higher degree of economic freedom is one where the imposed transaction costs are lower, and vice versa. ${ }^{13}$

Of course, this distinction between market and state imposed transaction costs should be the subject of a distinct approach, a very fruitful one from an empirical point of view, concerning economics of transition, economics of crises and, generally, all cases of institutional reform.

\section{The Coase Theorem}

In economic literature, the Coase Theorem is the most popular link between property rights and transaction costs. This theorem says that resource allocation does not depend on the distribution of property rights in the absence of transaction costs. In the meantime, the Coase Theorem shows the crucial importance of transaction costs when explaining the counterfactual distribution of property rights.

One may say that individuals try to maintain their existing property rights and to establish new ones if the former are not sufficient, thus leading to a property rights approach based on transaction costs. Such a definition was given for the first time by Allen (1991) and says that transaction costs are those involved in establishing and maintaining the existing property rights.

The Coase Theorem evolved from a simple argument as it was presented in "The Problem of Social Cost" into a very well known and discussed subject within the modern law and economics approaches (Medema 1995, 1998). Its evolution led to theoretical discussions on the one hand, and to both empirical and experimental analyses on its applicability on the other.

Coase argues that, from the economic point of view, the legal system, the one that affects transaction costs, should establish an institutional arrangement of property rights that favors the economic efficiency by means of minimizing harm or costs, broadly speaking (Coase, 1960: 2). On this subject, Coase (1960: 2-15) shows the importance of transaction costs while taking into consideration the nature of bargaining, or contracts that can be easily affected in a negative way. Negotiations are efficient as long as we speak about 
competitive markets-according to the well known and much mentioned hypothesis of zero transaction costs-where property rights are well defined and enforced. But the property rights are never perfect, as insists Allen (1997: 108): "even if property rights could be completely defined under the law, the threat of theft prevents perfect ownership in an economic sense."

Regarding the example of the crop damage caused by stray cattle, Coase offers an overview on the cattleman's marginal gains and farmer's marginal losses, as follows: neglecting the transaction and information $\operatorname{costs}^{14}$ and under perfect competition, the gain or loss for the "society" is the same, regardless of whether the cattleman compensates the farmer for the value of the lost crops-cattle were left to roam-or the farmer compensates the cattleman for the higher prices of the meat production - cattle were not left to roam on the farmer's crops. Given the conditions of perfect competition, Coase (1960: 6) concludes: "[w]hether the cattle-raiser pays the farmer to leave the land uncultivated or himself rents the land by paying the land-owner an amount slightly greater than the farmer would pay (if the farmer was himself renting the land), the final result would be the same and would maximize the value of production."

Coase's conclusion seems to be valid, but this is only if we take into consideration his restrictive and unrealistic assumption-zero transaction costs and perfect competition-and assume that the farmers have nothing to do with the sense of justice as far as property rights are concerned. He also assumes that the members of the society do not suffer any additional economic losses when the government refuses to make cattle owners responsible for the damage their animals cause. This means that property owners will experience no loss provided that Coase's theorem is used as a standard of judgment and a legal precedent. The reason that Coase's conclusion is not actually valid or realistic derives from the fact that he considers an unreal world, where transaction costs are defined according to the infallible model of an omniscient homo oeconomicus, capable of perfect foresight. His conclusion, therefore, is not applicable to the real world. Coase (1960: 15) himself never said this; his theorem only followed the basic assumptions presented by the Pigouvian theory around 1960. 
Public goods are a very good example of replacing the market failure model with one based on transaction costs. Samuelson (1954) considers public goods a class of market failures. An example is that of a lighthouse. Referring to this, Samuelson (1964) wrote about lighthouses as an example of government service. These public goods save lives and cargoes; but lighthouse keepers cannot reach out to collect fees from skippers. So, says Samuelson in this advanced treaty, "we have a divergence between private advantage and money cost... and true social advantage and cost... Philosophers and statesmen have always recognized the necessary role of the government in such cases of external-economy divergence between private and social advantage" (Samuelson 1964: 45).

But Cheung and North argue that the approaches of transaction costs and property rights are more than what Samuelson offers, and give more room for analysis. A great example is that given by Coase himself (1974), who argued that the British lighthouse system was once a well functioning private one and more complex than shown by the standard market failure diagnostic.

This is the point where, as shown by Medema and Zerbe Jr., we come to the real economic policy importance of the Coase Theorem:

The [t]heorem is not, in the end, about markets or about costless bargaining; rather, it is about the costs of coordination. If coordination is costless, markets function perfectly; but so does government. If coordination is costly, markets function imperfectly; but so does government. The task for legal-economic policy thus becomes that of ascertaining the magnitude and influence of these costs and the resulting implications for alternative institutional-policy arrangements. (Medema and Zerbe Jr. 1999: 877)

Even if one takes efficiency to be the goal of the legal-economic policy, Coase's theorem does not say anything about the ethics of private property rights and voluntary contract, or the superiority of the market mechanism over Pigouvian solutions. And all these by virtue of the transaction costs argument.

My own presupposition entirely distorts Coase's analysis-a presupposition that is all too common (and unstated) in the Chicago School of economic analysis: the legitimacy of leaving aside issues of right and wrong, of justice. Coase (1960: 19) says that "if market transactions were costless, all that matters (questions of equity apart) 
is that the rights of the various parties should be well-defined and the results of legal actions easy to forecast." But, as Gary North wrote,

How can we discuss "the rights of the various parties" if we leave aside questions of equity—questions of right and wrong? In short, how can we discuss "rights" apart from discussing what is morally right? This is the problem that the economics profession has faced from the beginning. Coase's essay denies the relevance of the question. That is the problem with Coase's essay. (North 1992: 40)

\section{Transaction Costs Relevance for Institutions' Efficiency}

The free market is a voluntary exchange system of legitimate private property rights; its rule is unanimity. When political constraints are absent, the free market process restructures behavior rules, constraints, and institutional incentives, and so encourages the exchange. Well defined and sure property rights are much easier to be exchanged than the insufficiently defined and uncertain ones. This does not demonstrate the fact that the exchange external observer can indicate the real nature of the exchanges' difficulties or measure the transaction costs' decreasing dimension, as an institutional efficiency appreciation instrument. On the other hand, transaction costs (the cost of using pricing systems in Coase's terms) can be presented as production costs' expansion, more or less important, taken into consideration or not, depending on the perceptions and subjective valuations of those involved in the market process.

The fundamental problem will be formulated as follows: What is the relevance of transaction costs for the methodological corpus of economic science? How can transaction costs be compatible with subjectivism (on which the theory of cost is founded) and with free market (as institutional arrangement that excludes coercion and relations of political power)? On the free market, the entrepreneurial approach reveals that transaction costs seem to have a very limited scientific value, perhaps only an explicative one, as logic of economic optimization.

For example, information about market opportunities is not and cannot be a free good. This natural feature of the market opens the problem of institutional arrangements, which creates the need of 
information for the exchange. Within a free market, resources are allocated, on a commercial basis, to an information production and selling direction: business consulting agencies, real estate agencies, and different service offices are all organizations involved in information production services. Also, great competition and legal practices in the contracts area are important sources for reducing uncertainty (for example, generalizing standard contracts and "commercializing" them and consolidating goods such as trust, or a good reputation).

The central argument of Ronald Coase's "The Problem of Social Cost" (1960) is the fact that volunteer exchanges, on the condition that property rights are well defined, represent the sufficient condition of efficiency. ${ }^{15}$ Coase completes this proposition with the so-called zero transaction cost clause. The approach suggests that, providing that there are zero transaction costs (which means a lack of uncertainty), resources' efficient allocation does not depend on the initial definition of property rights. If there are no transaction costs, the optimum solution would be reached, without considering the initial arrangements of property rights. As a paradox, this clause is the one that weakens Coase's arguments.

Coase's approach gained a lot of laudatory comments, but also contradictory ones and scientific criticism coming from great academic personalities who indicated serious errors concerning what is meant to be "law and property rights' economics." As Buchanan (1985: 93) shows, it is unfortunate that Coase presents his arguments in terms of objectively measurable cost-benefit relationship. In Coase's examples, these relations are perceived the same by all parties involved, despite any reference to subjectivism. So, the unique resource allocation exists and becomes conceptually undeterminable for every external observer. On the other hand, the zero transaction costs hypothesis would make resource allocation unable to be influenced by the property rights structure. In this case, the structure of property rights is of no interest.

This type of argument reveals that the economic analysis á la Coase cannot establish a scientific criterion for the economics of law or property rights economics; moreover, it cannot create an adequate medium for the positive approach of economic science. Furthermore, the impossibility of measuring the transaction costs reveals their 
irrelevance for evaluating the efficiency of the exchange, or for the efficiency of the alternative structures of property rights.

In a fundamental manner, the unrealistic character of the hypothesis used by Coase is argued. The costs that we deal with in economic science-opportunity costs-are a real-world phenomenon. Realworld behavior results from choices, and to choose means to do something and not to do other valuable things that could have been done instead (Hülsmann 2000). The costs of real-world behavior are the values of such real alternatives. However, transaction costs as Coase understands them can only be defined in terms of "alternatives" that have never been open to human beings and that never will. To be a human being means to act under uncertainty, which characterizes all the aspects of human action. It is therefore useless to hold up a perfect foresight as an ideal for real-world human action, this becomes (transactional) costly.

Hülsmann pointed out the irrelevance of Coase's hypothesis:

We do not wish to insinuate that it is useless to compare our real world with fictitious other worlds. The point is to be careful in defining and using fundamental concepts lest we invalidate analyses of the real world. The cost concept underlying Coasian transaction costs has nothing to do with the opportunity costs that we use in economic analysis. Rather, transaction costs have affinities with what a distinguished follower of Coase has called "the nirvana approach"17_identifying "inefficiencies" in our world through comparisons with a perfect-foresight nirvana. This is a deficiency that vitiates Coasian explanations of the emergence and transformation of social institutions. (Hülsmann 2004: 50)

So, it is misleading to say that those practices and institutions spring from a special type of cost-transaction costs. And it is somehow wrong to conclude that one can explain the evolution of those practices and institutions in terms of transaction costs. Explanations that rely on the nirvana approach can be more or less exciting literature, but they add nothing to science. Valid explanations of human action and human institutions must stress real-world choices among real-world alternatives. This approach has been known before 1937, it is called methodological individualism.

If the entire Coasean approach is analyzed in the light of methodological individualism, then there is no way for the external observer to determine the identical character of the exchange for the perception 
of all the involved parties. If person A refuses an $\mathrm{X} \$$ offer for good $\mathrm{T}$, then one can suppose that person $\mathrm{A}$ considers that good $\mathrm{T}$ has a greater value than $\mathrm{X} \$$. In a certain institutional frame in which $\mathrm{A}$ and $B$ are parties of a potential exchange, the absence of exchange reveals that $\mathrm{T}$ remains in its most valuable utilization. Therefore, in a given institutional environment, resources will be efficiently allocated as long as the parties involved are free to participate or to refuse the exchange. ${ }^{18}$

Given other conditions than the free market, the judgment of transaction cost-as an obstacle for the exchange-could obtain an intuitive significance, which would consist of appreciating the ability of institutions to favor social cooperation and prosperity. Every governmental policy is defined by exerting coercion on certain categories of people. Every state's policy means, on the one hand, instituting the obligation of some exchanges that would not have voluntarily proceeded in the absence of governmental interference, and on the other hand, outlawing exchanges that would otherwise have voluntarily proceeded. These events influence the social cooperation, by reducing the amount of voluntary exchange.

What happens when, for example, the legal system institutes property rights on land, but not on transacting it as well? In this circumstance the Coasean economist would blame transaction costs-their increase being synonymous with a greater inefficiency. Actually, inefficiency is the result of altering property rights, by the interference of the political system that obstructs the market in creating prosperity. Thus, it would be a glaring mistake to explain the perpetuating of underdevelopment through high transaction costs. But what kind of transaction costs, market or state imposed transaction costs? Without this dichotomy, it would mean to ignore the way the state policies rise against property rights. Understanding this opens Pandora's box over state imposed transaction costs, showing the pattern of an institutional arrangement in opposition to the principles of economic development.

The market process cannot develop in an institutional vacuum. Any efficient resource allocation is necessarily influenced by the structure of rules and rights, defining the institutional environment in which the decisions of evaluating and using resources are taken. Naturally, 
resources have a different allocation in different institutional arrangements. However, this means nothing more than the fact that people act differently in different structures of constraints and incentives. As a result, the structure of property rights-the institutional environment—cannot be a neutral one.

In the world of Coase, in which there are no transaction costs, the allocation of resources will not be altered by the structure of property rights. This famous idea is as useful as the fact that in Eden all people are omniscient. In the real world, the opposite aspect becomes true: when transaction costs are positive, the allocation of resources is altered by the structure of property rights. By virtue of this conclusion, the school of economic analysis of law has transformed the transaction costs into the paradigm of New Institutional Economics (Eggertsson 1990). For the economists (see Coase 1993) of the Chicago School, efficiency is the criterion for institutional solutions. Thus, the ethics of private property have tenuously been substituted by the cost-benefit criterion. From such a utilitarian approach there arises the ill-fated "need" for law as an instrument of maximizing social wealth: it is what the judge Richard Posner (1983) argues for.

The corollary of Posner is that, on the condition that there are high transaction costs. ${ }^{19}$ efficiency will result when the court offers the rights to the one who will evaluate them in the highest degree. ${ }^{20}$ According to Coase (1991:253), "it is obviously wishful that the rights should be distributed to those who can use them at their highest efficiency, and for achieving and maintaining such a distribution, the cost of transfer for these rights must be minimal and the law must favor its achieving." In this approach, Coase and Demsetz plead for the allocation of property rights in any structure that will minimize the social transaction costs. ${ }^{21}$ In other words, if by aggregating individual costs and incomes we obtain a "social net income," then the policy that created this income is desirable, no matter the degree of coercion. It reflects the unfortunate aspect that for Coase (1960: 15), "the economic problem, in every case of negative economic [externality] effect, is maximizing the value of production." This view clearly indicates the subordination of private property ethics in favor of arbitrary considerations over their monetary efficiency. 
The subjectivism of efficiency, as well as the impossibility of interpersonal comparison of utility, demonstrates why efficiency cannot be a scientific criterion-especially in evaluating law, property rights, or state policy. Something else, like ethics, must be the reference point for social science. ${ }^{22}$ Even though there is a general understandingamong economists - that individual utilities cannot be measured, and thus compared, they still sum up and subtract social benefits and social costs. As proof for this statement are the analyses of the scientific evaluation of benefits and losses in welfare for the entire society, and for the national economy. Moreover, there are a number of studies such as: "The costs and benefits of Romania's accession to EU," in which it is of little importance that economists have their hands bound in measuring and comparing advantages (for some) and costs (for others). What remains is purely political speculation.

Finally, the Orthodox Coasean Economics founded by Coase (1960), Stigler (1966), and Demsetz (1966) postulate, an epistemological misunderstanding, concluding that the initial distribution of property rights, whether irrelevant or not, must be subordinated to the criterion of monetary value maximization of social production. In fact, the cost-benefit criterion ruins the entire efficiency theory when the one negotiating the negative externalities that are imposed to him would shout "Coase, get your cattle off my land!'-as Walter Block did say in 1974, at the South Royalton Conference for Austrian Economics. Such a proposition-simple and eloquent—synthesizes the best the unhappy ethical implications of the famous Coase Theorem as far as solving the problem of property rights violation on the economic efficiency criterion is concerned.

So, the transaction costs paradigm, the cost-benefit economic analyses, and generally, the institutions' efficiency problem are all subordinated to the ethics criterion, namely the principle of private property rights that encompasses all market economy's institutions.

If today institutional economics is an economics of the rules, then transaction costs cannot represent the ultimate indicator to analyze the social rules efficiency. That is because, especially in this domain, efficiency is what comes out of respecting the ethical rules. Therefore, what is really important for the New Institutional Economics, contrary to Douglas North, does not have anything to do with com- 
bining the human action theory with the transaction costs theory. Fundamentally, however, it has to do with the (more or less rationalist) identification of the rules of ethical human action and the rule of law, namely those ethical and, in corollary, favorable institutions for economic development.

\section{Notes}

1. In Douglas North's model (1990: 3), institutions are the rules of the game in the society, which are the constraints and incentives that shape the social cooperation process. These rules-spontaneously emerged or "pragmatically" designed-are adopted by individuals depending on the way they succeed to solve the social cooperation problems. In fact, as Kasper and Streit (1998: 28) show, institutions refer to the rules in the society (but not physical or natural limits) that constrain opportunistic behavior that can be adopted within interpersonal relations.

2. Jules L. Coleman (1984: 666) writes: "No term in the philosopher's lexicon is more imprecisely defined than is the economist's term 'transaction costs'. Almost anything counts as a transaction cost. But if we are to count the failure to reach agreement on the division of surplus as necessarily resulting from transaction costs (I have no doubt that sometimes it does), then by 'transaction cost' we must mean literally anything that threatens the efficiency of market exchange. In that case, it could hardly come as a surprise that, in the absence of transaction costs so conceived, market exchange is efficient."

3. Coase, "The Nature of the Firm" [1937], in The Firm, the Market, and the Law, Chicago: University of Chicago Press, 1990, pp. 33-56.

4. While "The Nature of the Firm" (1937) introduced the thenrevolutionary concept of transaction costs into economic theory, in "The Problem of Social Cost" (1960) the concept was further developed by emphasizing the effect of the law on the working of the economic system. In the field of institutional economics, even Coase used the discovery of transaction costs, but ironically, these words are absent from many of its titles. Coase provides examples of what he meant by the "costs of the price mechanism": discovering what the prices are, negotiating and closing a contract, but he stops just before giving a definition. In fact, throughout all his writings, Coase never goes beyond providing examples of transaction costs.

5. In his magnum opus Human Action, Ludwig von Mises (1966: 102) shows that "value is the importance that acting man attaches to ultimate ends. Only to ultimate ends is primary and original value assigned. Means are valued derivatively according to their serviceableness in contributing to the attainment of ultimate ends. Their valuation is derived from the valuation of the respective ends. They are important for man only as far as they make it 
possible for him to attain some ends. Value is not intrinsic, it is not in things. It is within us."

6. Buchanan (1969, 1973, 1979) and Buchanan and Thirlby (1973).

7. In The Essential von Mises (1973, www.libertarianpress.com/rothbard/ essential/toc.htm), Murray Rothbard shows that, although not translated until well after World War II, Mises' ideas on methodology were brought to the English speaking world in a highly diluted form by his student and follower at the time, the young English economist, Lionel Robbins. Robbins' "Essay on the Nature and Significance of Economic Science" (1932), in which the author acknowledges his special indebtedness to Mises, was acknowledged for many years in England and in the United States as the outstanding work on the methodology of economics.

8. Despite the fact that the cost and choice theory has especially subjective foundations, I emphasize North's empiric attempt to measure transaction costs. According to Wallis and North (1986), in the United States economy more than 45 percent of national revenue is represented by transactions allocated resources. Based on this analysis, the authors emphasize the transaction costs and services were an increasing dimension within the analyzed period (1870-1970). So, I intend to introduce an alternative approach: transaction costs do not represent exclusively the reflection of the exchange barriers. On the free market, transaction costs also represent, and probably in a more important sense, the existence of greater profit opportunities (exchange ones). So, transaction (coordination) costs' increasing dimensions represent the institutions and institutional arrangements' result itself, presented within the labor division and exchange process. Increasing the relative dimension of transactions within the services area represents the mechanism of transaction costs' attenuation and also the mechanism of the revaluation of as many exchange opportunities as possible.

9. See, for this, the institutional reforms developed in China, generated by the entrepreneurship, which have become a factor of political pressure directed toward the relaxation of formal legislation in business.

10. Simply by complying with the institutional constraints, the creative and the anticipative ability of the entrepreneurs will be completely ignored. That is why an entrepreneurial approach of the institutions is necessary.

11. The "misallocation" term is used by Kirzner referring to an inefficiency allocation, to a presumed lack of coordination of individual plans.

12. For example, only if we refer to the pile of documents that have to be filled in order to pay taxes, to the army of lawyers that business people hire in order to save money as regards the Treasury do we have the image of the economic significance of what it costs us to comply with the law. The fact that, everywhere in the world, transfer of property or notary legalization of contracts are accompanied by some costs to comply with the law does not mean that property transfer or notary authentication go on as easy or 
difficultly, irrespective of the institutional system. In regards to the extent of the imposed transaction costs, there are significant differences from one country to another, from one institutional system to another.

13. For example, the imposed transaction costs are higher in a business environment, where there are many state regulations, burdening taxation, legislative instability, and corruption. Thus, phenomena such as institutional frailty, corruption, and state captivity define the way in which the real institutional arrangement imposes significant transaction costs that manage to affect economic performance.

14. In the terms of Coase (1960: 2), "when the damaging business has to pay for all damage caused and the pricing system works smoothly (this strictly means that the operation of the pricing system is without cost)."

15. Within the externalities theory frame, Coase argues that free exchange between parts shows that all Pareto-relevant externalities tend to be eliminated.

16. I mention here some of the most critical replies against "The Problem of Social Cost" and Coase's economic analysis of the law: Walter Block (1995: 61-125, 1997: 111-115), Cooter (1982), Rothbard, (1997, 1982), North (1992), and Buchanan (1985: 92-107).

17. Demsetz (1969); to avoid misunderstandings, let us emphasize that our present criticism concerns only the concept of transaction costs. Coase's precept for judges and legislators-maximize social product, minimize social costs-is coined in terms of relevant alternatives and thus avoids the nirvana fallacy. As I have argued above, however, this precept suffers from other serious shortcomings.

18. Given other conditions than the free market, the judgment of transaction cost-as an obstacle for the exchange-could obtain an intuitive significance, which would consist in appreciating the institution's ability to favor social cooperation and prosperity. Every governmental policy is defined through exerting coercion on certain groups of persons.

19. If transaction costs are low, as writes Ellickson (1989: 619), this does not imply that "Coasean" bargaining exists. Also, I wonder who establishes, on a free market, what high or low transaction costs mean?

20. For Posner (1983), "this is the economic reason which entitles the worker to sell his labor [sic], and the woman to chose her sexual partners," which means the impossible perspective to establish rights according to the intensity of their evaluation (the efficiency criterion), not on grounds regarding the ethics of private property.

21. For example, Demsetz (1966: 66) writes that "it will be efficient to assign new property rights in a way that is expected to minimize the cost of transacting that will be required subsequently."

22. In accordance with the Austrian School of Economics and with one of its most pre-eminent teachers—Murray Rothbard (1998)—I think that the only 
fundamental criterion that can confirm the scientific nature of economics is the criterion of ethics. As I shaw in one of my books (Marinescu 2004), the economic judgments are complete when they are placed in an ethical environment, as long as law and ethics are naturally connected and are the essential means for a right understanding of society and human nature.

\section{References}

Allen, D. W. (1991). "What are Transaction Costs?" Research in Law and Economics 14: 1-18.

. (1997). "Property Rights, Transaction Costs and Coase: One More Time." In Coasean Economics: Law and Economics and the New Institutional Economics. Ed. Steven G. Medema. Dordrecht: Kluwer Academic Publishers.

Barzel, Y. [1989] (1997). Economic Analysis of Property Rights. $2^{\text {nd }}$ ed. Cambridge University Press.

Block, W. (1995). "Ethics, Efficiency, Coasian Property Rights, and Psychic Income: A Reply to Demsetz." Review of Austrian Economics 8(2).

—. (1997). "Coase and Demsetz on Private Property Rights." Journal of Libertarian Studies I(2).

Buchanan, J. (1969). Cost and Choice: An Inquiry in Economic Theory. Chicago: Markham Publishing Company.

—. (1973). "The Coase Theorem and the Theory of the State." Natural Resources Journal (13).

- (1979). What Should Economists Do? Indianapolis: Liberty Press.

- (1985). Liberty, Market and State. New York: New York University Press.

Buchanan, James M., and G. F. Thirlby (eds.). (1973). L.S.E. Essays on Cost. Birkenhead, UK: Willmer Brothers Limited.

Cheung, Steven N. S. (1978). The Myth of Social Costs: A Critique of Welfare Economics and the Implications for Public Policy. London: Institute of Economic Affairs.

Coase, R. (1937). "The Nature of the Firm." Economica, New Series 4(16): 386-405.

— . [1960] (1990). "The Problem of Social Cost." In The Firm, the Market, and the Law, ch. 5, pp. 95-156. Chicago, IL: University of Chicago Press.

—. (1974). "The Lighthouse in Economics." Journal of Law and Economics 17(October).

—. (1991). "The Institutional Structure of Production." In Essays on Economics and Economists. Ed. Ronald Coase. Chicago, IL: University of Chicago Press.

—. (1993). "Law and Economics at Chicago." Journal of Law and Economics (36). 
Coleman, J. L. (1984). "Economics and the Law: A Critical Review of the Foundations of the Economic Approach to Law." Ethics (94).

Cooter, R. (1982). "The Cost of Coase." Journal of Legal Studies XI.

Demsetz, H. (1966). "Some Aspect of Property Rights." Journal of Law and Economics 9: 61-70.

— (1969). "Information and Efficiency: Another Viewpoint." Journal of Law and Economics 12(1).

Eggertsson, T. (1990). Economic Behaviour and Institutions. Cambridge: Cambridge University Press.

Ellickson, R. C. (1989). "The Case for Coase and Against 'Coaseanism'." Yale Law Journal.

Hayek, Friedrich. (1945). "The Use of Knowledge in Society." American Economic Review 35(4): 519-530.

Hülsmann, J. G. (2000). "A Realist Approach to Equilibrium Analysis." Quarterly Journal of Austrian Economics 3(4).

—. (2004). "The A Priori Foundations of Property Economics." Quarterly Journal of Austrian Economics 7(4).

Kasper, W., and M. E. Streit. (1998). Institutional Economics: Social Order and Public Policy. The Locke Institute. Cheltenham, UK: Edward Elgar.

Kirzner, I. (1963). Market Theory and the Price System. New York: Van Nostrand Co.

Marinescu, C. (2004). Institutions and Prosperity. From Ethics to Efficiency (in Romanian). Bucharest: Economica Publishing.

Medema, S. G. (ed.). (1995). The Legacy of Ronald Coase in Economic Analysis. Aldershot: Edward Elgar Publishing.

- (1998). Coasean Economics: Law and Economics and the New Institutional Economics. Dordrecht: Kluwer Academic Publishers.

Medema, S. G., and R. O. Zerbe Jr. (1999). "The Coase Theorem." In Encyclopedia of Law and Economics. http://users.ugent.be/ gdegeest/ 0730book.pdf

Menger, C. [1871] (1994). Principles of Economics. Libertarian Press, Inc.

Mises, L. von. (1966). Human Action. A Treatise on Economics. $3^{\text {rd }}$ ed. Chicago: Henry Regnery Company.

North, D. C. (1990). Institutions, Institutional Change and Economic Performance. Cambridge University Press.

North, G. (1992). The Coase Theorem. A Study in Economic Epistemology. Institute for Christian Economics.

Pejovich, S. (1995). Economic Analysis of Institutions and Systems. Kluwer Academic Publishers.

Posner, R. (1983). Economics of Justice. Cambridge, MA: Harvard University Press.

Rothbard, M. N. (1982) "Law, Property Rights, and Air Pollution." Cato Journal. 
. (1997). The Logic of Action: Method, Money, and the Austrian School. Cheltenham UK: Edward Elgar Publishing.

- (1998). The Ethics of Liberty. $2^{\text {nd }}$ ed. New York: New York University Press.

Samuelson, P. A. (1954). "The Pure Theory of Public Expenditure." Review of Economics and Statistics (36).

-. (1964). Economics: An Introductory Analysis. $6^{\text {th }}$ ed. New York: McGraw-Hill.

Stigler, George J. (1966). The Theory of Price. $3^{\text {rd }}$ ed. New York: Macmillan.

Wallis, J., and D. North. (1986). "Measuring the Transaction Sector in the American Economy, 1870-1970." In Income and Wealth: Long-Term Factors in American Economic Growth. Eds. Engerman, Stanley L. and Gallman, Robert. Chicago: University of Chicago Press.

Williamson, O. (1979). "Transaction-Cost Economics: The Governance of Contractual Relations." Journal of Law and Economics 22(2): 233-261.

Williamson, Oliver, and S. Winter (eds.). (1991). The Nature of the Firm. Oxford University Press. 